Article

\title{
Religious Belonging in the East Asian Context: An Exploration of Rhizomatic Belonging
}

\author{
Daan F. Oostveen 1,2 (D) \\ 1 Faculty of Religion and Theology, VU Amsterdam, De Boelelaan 1105, 1081 HV Amsterdam, \\ The Netherlands; dfoostveen@protonmail.com \\ 2 Faculty of Philosophy, Renmin University, 59 Zhongguangcun Street, Beijing 100872, China
}

Received: 7 December 2018; Accepted: 7 March 2019; Published: 12 March 2019

\begin{abstract}
This article explores the hermeneutical challenges to understand religious belonging and religious identity in the East Asian context. In East Asia, religious identities have not always been as exclusively delineated, as is the case in Western models of religious diversity, for example in the so-called World Religions paradigm. Various theoretical frameworks are discussed in religious studies, sociology and anthropology of religion in China and East Asia, to acquire a better understanding of religious belonging. It is observed that two hermeneutical frameworks are used by scholars to discuss religious diversity: a hermeneutics of multiple religions and a hermeneutics of religiosity. The former analyses "religious belonging" as a "belonging to religious traditions". In the latter, "religious belonging" is understood as transcending particular religious traditions. It is argued that we need to take another look at the philosophical concept of "multiplicity" to understand religious diversity and religious belonging. We can use the Deleuzian concepts of "rhizome" and "assemblage" to describe religious belongings in East Asia specifically and also religion in general. A rhizomatic thinking about religion enables us to reimagine the concept of religious belonging as rhizomatic belonging, and also, as is argued by Haiyan Lee and Mayfair Yang, make it possible to subvert power structures inherent to religion.
\end{abstract}

Keywords: religiosity; religion; belonging; Daoism; Buddhism; rhizome; hermeneutics

\section{Introduction}

In East Asia, religious identities have not historically been as clearly demarcated as in cultures which have been dominated by monotheistic religions (Yao and Zhao 2010). Neither Buddhist nor Daoist identities have historically had the same exclusivist connotations as is often the case with people in Christian or Muslim cultures. There appears to be a difference between the laity and religious professionals regarding religious self-identification. Whereas religious professionals in East Asia are usually conscious about religious differences, for the laity the boundaries between religious traditions in East Asia have usually been less clearly demarcated, if not in theory then at least in practice. In his contribution to this special issue, Fenggang Yang explains this as follows: "[ . . ] in the Judeo-Christian context, it is assumed that religious identity is exclusive, that every religious person is a member of a local congregation that is part of a denomination or a distinct religion, and that regular activities include weekly attendance at a corporate worship service. However, East Asian religions have distinct characteristics: Religious identity is not necessarily exclusive, religious practice is not based on a weekly rhythm, individual devotion or practice is at least as important as corporate rituals, and the boundaries of religiosity and secularity are ambiguous or blurred" (Yang 2018). In this article I will extend the concept of religious belonging beyond self-identification with religious traditions. I will propose rhizomatic belonging as a form of religious belonging which is suitable for the "hybrid" religious ecology which is characteristic to East Asia. Furthermore, it might be suggested that also in the Western world, religious belonging is increasingly transforming towards this model. I will focus on China as a case study 
exemplary for East Asia. Though the idea of "religious belonging" does not appear evident in the Chinese setting, I believe it can clarify an important dimension of religion in general.

\section{Religious Belonging}

What does it mean to have a "religious belonging" in China? What does it mean to be a Daoist? What is a Buddhist identity and is there such thing as a "Buddhist belonging"? Although these questions appear to be straightforward, they open up a whole range of problems. In this article I aim to extend the concept of religious belonging beyond the understanding of this concept as self-identification with a religious tradition. "Belonging" refers to a much deeper amalgam of connections with religious forms then just "identity". Furthermore, it has a strong affective dimension which is often overlooked, and which is not adequately expressed when we understand it only as a concept of classification. If we look into the nature of religion in China and East Asia, we can question whether there exists something we could call a "belonging to Buddhism" or a "belonging to Daoism" in the same way as we immediately understand what a "belonging to Christianity" means. Even if we understand what such a belonging (to Buddhism, or Daoism, or Confucianism) might mean, we could still question what such a belonging would look like. Fenggang Yang states that "[ ... ] there is [ ... ] a cultural tendency of not formally joining any particular religion, which is a consequential "habit of the heart" formed by centuries of religious repression (Yang 2016). If we want to understand what religious belonging is, we first have to see what it is not. Therefore, we have to compare various forms of religious belonging in East Asia, such as Buddhist belonging, Daoist belonging, Confucian belonging, Christian belonging, the absence of religious belonging or multiple religious belonging.

In Western theology and religious studies, there has been an increased attention on multiple religious belonging in Western contexts (Schmidt-Leukel and Bernhardt 2008; Cornille 2010; Rajkumar and Dayam 2016; D'Costa and Thompson 2016). So-called "pioneers" are sometimes combining the identities of diverse religions such as Buddhism and Christianity to form a "dual belonging" or a "multiple religious belonging". From this perspective, scholars have sometimes suggested that these Western forms of multiple religious belonging point at an "Easternization" of religious belongings. It is hypothesized that religions in East Asia have not usually been defined by means of exclusive identities with distinct boundaries, as is more common in the Western understanding of religious diversity. Therefore, the assumption goes, individuals can more easily adopt a multiple religious belonging.

These forms of religious belonging, mentioned above, still assume an identification with religious traditions. Next to religious identities and belongings based on self-identification with "religious traditions" we also see phenomena such as popular religiosity, shamanism and hybrid cultural expressions, where the issue of belonging as self-identification is much less clear-cut, if not absent. It seems that "belonging" as a marker of religion can be applied much broader than on self-identification to religious traditions alone. In a recent survey on the state of religion in China, it turned out that 215 million Chinese people confessed to believing in the spirits of the ancestors; 362 million Chinese people had participated in divination practices such as face reading and fortune telling in the past year; and a stunning 754 million people practiced ancestor worship (Wenzel-Teuber 2012). There appears to be a stark contrast between practicing "religion", as it is usually understood in Western scholarship, and identifying with (a) religion. Besides an absence of "belonging", even the legitimacy of these practices has also been widely questioned and have sometimes been labeled as "superstition" or rejected as "magic" (Palmer and Goossaert 2011; Hanegraaff 2016). These numbers are in stark contrast to the official or common understanding of China as a predominantly "atheist" country; they also stand in contrast to the 185 million people who consider themselves as Buddhists (Wenzel-Teuber 2012)—which would be the largest "religion" in China in terms of self-identified adherents.

The situation in the case of Daoism is even more interesting: only 12 million people in the People's Republic of China self-identify as "Daoists", while at the same time 173 million people "had some kind of Daoist practice" (Wenzel-Teuber 2012). Assuming these numbers draw an accurate picture, we could conclude that only approximately $7 \%$ of practicing Daoists also self-identity as such. 
Palmer and Siegler (2018) notes: "while one can be the disciple of a master or the follower of a specific sect, there has never been a concept of 'membership' in Daoism as a unified 'religion'". As a religious tradition of teachings of self-cultivation and longevity, Daoism appears to eschew the foundational understanding of "religions" as primarily defined by means of exclusive beliefs by "followers" who self-identify with one and only one religion, excluding others. Though we could conclude from this that Daoism is not a "religion" as compared to an ideal type, Daoism might give us the opportunity to even better understand the phenomenon of religion, precisely because it lacks a strong sense of popular self-identification, but instead creates assemblages of ritual and symbols to which many different people can connect.

Historically, religious diversity in China has not been characterized necessarily by competing and exclusive religions with different truth claims, but as complementary, often pragmatically oriented, systems of thought. This is also expressed in the word which was commonly referred to Buddhism, Daoism, and Confucianism (or Ruism), namely as jiào教, “teachings". Religious teachings didn't have a similar institutional backing as has been common to the churches in post-reformation Europe. Throughout much of its history, China had a much stronger state bureaucracy than Europe, where church institutions functioned sometimes as de facto states or had a strong influence on politics. Religious traditions in China rarely had this much political clout, were subordinate to strong state structures and therefore its boundaries would often be more porous. The Chinese state and Chinese religions should be seen as inseparable from each other (Lagerwey 2010); emphasis on the "difference" between religions is therefore subordinate to the unity of the Chinese state. In China, "belonging" has not usually been understood as a function of "religions". Instead, "belonging" expresses a relation to the family, to the village, and to the country, to which various ritual obligations are attached.

In the Western world, scholars have witnessed the emergence of hybrid forms of religiosity; individuals who do not identify or belong to one religious tradition but identify with or combine elements from multiple religious traditions. In theology, this phenomenon has been called "multiple religious belonging", with a main focus on dual belongings to Christianity and Buddhism, Judaism and Buddhism or Christianity and Hinduism. Many people, however, appear to combine elements from various religious traditions without feeling a desire to identify or belong to any particular tradition. With this emergence of religious hybridity in the West (Pew Forum on Religion \& Public Life 2009; Berghuijs 2017), this understanding of a detachment between "belonging" and "religion" is becoming increasingly relevant in these contexts as well.

In contemporary sociological and anthropological reflections on religious diversity in China, some scholars have emphasized religious practices and the way religion is expressed through various religious modalities (Chau 2011). Chau distinguishes between four such modalities: the discursive or scriptural, the personal-cultivational, the liturgical, the immediate-practical, and the relational. His approach leads the focus away both from the differentiation of "religions" as the primary means of categorization and from an exclusive emphasis on doctrinal content, and instead emphasizes how religion works and what goal it serves. Ordinary Chinese people approach religion often with an aim towards efficacy, and much less towards doctrinal content. Religious teachings are often not entities of which ordinary people are aware, nor something which invokes a feeling of belonging to these teachings and traditions. Only religious elites have a more explicit awareness of distinct religious teachings and traditions, and thus are closer to the notion of "belonging to religions". These elites are specialized in the ritual content of religious traditions. But even for them it is possible to be trained in multiple religious traditions. They would act as either a Buddhist or a Daoist priest for example, depending on the circumstances.

'Religion' as a term is not native to East Asia (Goossaert 2005). Religion has been introduced as a result of Western scholarship and has found application to describe the Three Teachings of China, Daoism, Confucianism and Buddhism, as well as Islam and Christianity. But more contemporary sociological scholarship on religion in China has also applied the term to "popular religion": religious practices which cannot be clearly delineated as part of a single coherent tradition but are diffused 
practices throughout the country. Also, in the West, "religion" is a contested term (Smith 1998). While in some contexts it refers to "religious traditions", it can also appear in its adjective meaning, namely religion as "the religious" or "religiosity" as a separate domain of human culture, which is commonly contrasted to an oppositional domain of culture, namely "the secular" (Asad [1994] 2009; Yang 2008). Neither of these understandings are native to the historical worldviews of China. As is well known, the term "religion" zōngjiào宗教 was only introduced in China in the early 1900s. The development of these understandings of "religion" in modern Western scholarship has had an enormous impact on the self-understanding of cultural diversity in China and East Asia as well. One example is the identification and therefore elevation to the status of World Religion of "Buddhism", of which Masuzawa (2012) argued that "Buddhism" connected formerly dispersed religious practices throughout Asia and subsumed them under this powerful label (although her analysis has also been disputed by other scholars).

It is important to distinguish between these two meanings of the word "religion" in religious studies-though these two meanings sometimes intersect. The first meaning of "religion" refers to a class concept "religion", with several instantiations, "religions", such as Christianity, Islam, and Buddhism. Within this, what I call, "hermeneutics of multiple religions", individual people belong to one of several "religions" or to none at all. This "hermeneutics of multiple religions" is a generalization of what has been called the "World Religions paradigm" (as it has been proposed by Masuzawa (2012), and in the Chinese context further explained by Hedges (2017)), which is a way of understanding "religions" as exclusive systems of faith, while acknowledging that there are several "options". Hedges (2017) distinguishes three characteristics of the World Religions paradigm. First, the concept of religion in the World Religions paradigm implies bounded territories of belonging. Simply put, one cannot belong to both Christianity and Islam at the same time. Secondly, Hedges argues, belonging to a religion means primarily the belief in a set of principles. Because these principles are perceived to be different in different religions, it follows naturally that an individual cannot belong to more than one religion. Finally, Hedges says, religions are seen as "[their] own internally coherent and regulated entity".

The second meaning of "religion" refers to it as a particular form of human culture: "religious culture". In this meaning, "religion" is more comparable to a concept such as "spirituality"; the class concept of "religion" is rejected. Several social scientists of religion in China, such as Mayfair Yang and Adam Yuet Chau, have pointed out that the class concept of "religion" does not always make much sense in a non-Western context. Rather, they suggest we should talk about "Chinese religiosities" (Yang 2008). In this "hermeneutics of religiosity", the word "religion" does not refer to "religions" in the meaning of "religious traditions", but rather to an amalgam of different religious life forms.

There has existed a "hermeneutics of multiple religions" throughout the history of China. From the moment Buddhism arrived in China, religious elites have emphasized doctrinal and ritual differentiation as well as legitimation of these differences, although there was an equal amount of borrowing occurring between these traditions. The most important hermeneutical model has been the differentiation and harmonization of the Three Teachings: Confucianism, Buddhism, and Daoism. According to David Palmer, the religious teachings of China have been distinguished in three different ways (Palmer 2013). First, a differentiation between "Inner" and "Outer" teachings. Daoism or Buddhism have often been counted as "Inner", while Confucianism was regarded as an "Outer" teaching. Second there is a differentiation between "Civil" and "Martial" teachings. Civil are the universal teachings, which are applicable to anyone within the Chinese state structure. "Martial" teachings are the locally present religious rituals and deities. The first explanation professes the conviction that the three religious teachings originate from the same source and are thus different expressions of a common religious origin. The second explanation considers the Three Teachings as complementary, but functionally different. Each teaching serves a different goal. Confucianism is then for example a teaching with a mental function, Daoism a teaching with a physical function and Buddhism a teaching with a spiritual function. A third 
explanation considers different teachings as different methods to reach a common goal. They are distinct roads, which will all lead to the same goal, though some may take longer than others.

\section{Reimagining Religious Belonging}

I aim at reimagining "belonging" to be applied to religion in East Asia beyond "(self)-identification with religious traditions". The hermeneutics of religiosity and the hermeneutics of multiple religions are two different ways of looking at the same phenomena. The idea of "religious belonging" has been strongly connected to this second framework. But the hermeneutics of religiosity foregrounds the hybrid nature of religious forms, which, we could say, has been more present in East Asia. The context of China teaches us that "belonging" is an idea of connection that generally transcends the mere phenomenology of religious traditions. The feeling of belonging is deeply connected to the religious. Religiosities are constitutive in any person's feeling of belonging. I propose therefore that we reimagine the concept of religious belonging to fit in a hermeneutics of religiosity. Such a belonging can no longer be a function of "religious traditions". However, we should also remain aware not to arrive at a sort of "universal" belonging, which would transcend from all particularity of the context of the individual. Each person finds themselves at a crossroads of cultural forms, and it is out of these interactions that a feeling of belonging arises.

In a hermeneutics of religiosity, "the religious" refers to another form of multiplicity: not the multiplicity of "religious traditions" but, in the words of Hent de Vries, it refers to religions "words, things, gestures, powers, sounds, silences, smells, sensations, shapes, colors, affects and effects" (De Vries 2008). The French philosopher Gilles Deleuze has developed, together with Félix Guattari philosophical concepts to deal with such a "multiplicity" (Deleuze and Guattari [1980] 1987). For this work, he is mainly indebted to the philosophical thinking of Henri Bergson. In particular the concepts of the rhizome and assemblage (French: agencement) can function to reimagine religious belonging to fit into a hermeneutics of religiosity. The philosophical concept of the rhizome is derived from biology and functions to represent non-hierarchical connections between multiple elements. In biology, the rhizome refers to a subterranean stem of a plant, which sends roots and shoots from its nodes. Deleuze and Guattari use this concept as a metaphor that "'maps' a process of networked, relational and transversal thought, and a way of being without 'tracing' the construction of that map as a fixed entity" (Parr 2010). Furthermore, they see the rhizome as something that "conceives how every thing and every body—all aspects of concrete, abstract and virtual entities and activities—can be seen as multiple in their interrelational movements with other things and bodies" (Parr 2010).

One of the problems of the "arborescent thought" common to a hermeneutics of multiple religions, is that the particulars that are classified under the organizing principle or the taproot have no interaction with each other. In the Deleuze dictionary it is explained that in the arborescent schema "[t]he subordinate elements, once so arranged, are unable to 'move' horizontally in such a way as to establish creative and productive interrelationships with other concepts, particulars or models". If religious diversity is understood as a diversity of horizontally distinguished religions, as instantiations of an overarching concept "religion", this religious diversity has by definition become solidified and lacks the possibility of "creative and productive interrelationships".

This is opposed by the first two principles of the rhizome according to (Deleuze and Guattari [1980] 1987): connection and heterogeneity. They explain the first principle as "any point of a rhizome can be connected to anything other, and must be". A rhizome is characterized by connectivity. To explain heterogeneity, the concept of the assemblage is used to refer to "complex constellations of objects, bodies, expressions, qualities, and territories that come together for varying periods of time to ideally create new ways of functioning". The connective organization of the rhizome, as opposed to the hierarchic organization of the arborescent schema, enables assemblages to rise from these connections, which are always open to rearrangements.

The third principle of the rhizome is multiplicity. The multiple of the arborescent schema is not considered a real multiplicity, because it is ultimately reduced to the One. Deleuze and Guattari say 
"it is only when the multiple is effectively treated as a substantive, "multiplicity," that it ceases to have any relation to the One as subject or object, natural or spiritual reality, image and world".

The fourth principle of the rhizome is the principle of asignifying rupture. In the words of Deleuze and Guattari, this principle is directed "against the oversignifying breaks separating structures or cutting across a single structure". Furthermore, the principle describes that a rhizome "may be broken, [ ... ] but it will start up again on one of its old lines, or on new lines". This principle of the rhizome accounts for the continuity and discontinuity between religious traditions as structures or assemblages.

Principles five and six of the rhizome are cartography and decalcomania. In the words of Deleuze and Guattari "a rhizome is not amenable to any structural or generative model. It is a stranger to any idea of genetic axis or deep structure" and "the rhizome is altogether different, a map and not a tracing". When applied to religious diversity, these principles teach us that a rhizomatic hermeneutics prompts us not to look for the diachronical origins or the genesis of religion, but to focus on the "map" of religious diversity and the way in which religious phenomena are embedded in their environment.

In this line of thought, Michelle Voss Roberts has argued we should think about religiosity as an "omnicentered model of divine relationality values difference and connection; it helps us imagine persons as nodes in a rhizomatic generation of religious subjects in which no single center definitively determines identity" (Voss Roberts 2010, p. 59). We could say that a "rhizomatic hermeneutics" of religious diversity describes a spatial map of religion in which connections cross transversally. No single religious tradition is traceable back to a first origin. Rather, religiosity originates from many different places at the same time and connects at an immense multiplicity of nodes. What counts is not the unity of the tradition but the diversity of religious elements in the present. "Religions" are assemblages of a variety of heterogeneous religious elements. The concept of assemblage is used to signify social structures from a bottom-up approach. It is used to de-emphasizes fixed religious identities, but instead focuses on the fluidity and exchangeability of religious forms. Individuals connect with different assemblages and with different elements within those assemblages. Instead of a belonging to a fixed identity-structure, individuals should rather be seen as "at home" within fluid and transforming social structures, which emerge from the ground up.

The methodological emphasis on religiosity "as it is lived" - as opposed to an emphasis on theology, doctrine, and religious normativity as expressed by religious elite, was already developed by scholars such as Robert Orsi and David Hall. The framework of "lived religion" does not focus primarily on religious traditions or institutions, but instead on how religious practices are expressed in everyday social contexts. Many anthropologists have noted that the "boundaries" between religious traditions, such as they have been traditionally defined, often do not have much meaning for people in the expression of religiosity in their daily lives. Anthropologist Meredith McGuire writes: "when we focus on religion as lived, we discover that religion — rather than being a single entity-is made up of diverse, complex and ever-changing mixtures of beliefs and practices, as well as relationships, experiences, and commitments" (McGuire 2008). She questions whether boundaries between religious traditions are the best way to describe religious phenomena. She states for example that "[w]e seem to have uncritically accepted definitional boundaries that distinguish religious practices from one religious group from another's, viewing them as mutually exclusive" (McGuire 2008).

\section{A Critical Approach to Religion}

A rhizomatic hermeneutics, as I coin it, and as has been envisioned by Deleuze and Guattari, aims at destabilizing inherited power structures. Therefore, this conceptual shift has a normative dimension. Power could be regarded as inherent to religion. There exists a complex power dynamic between religious actors, both elites and lay expressions of religion in everyday life, politicians and governments, and religious studies scholars. In order to get a clear image of how religiosity functions in the context of East Asia, we have to consider these power dynamics. According to Mayfair Yang, rhizomatic thinking helps to redress social inequality. The concept of the rhizome takes into account that we can never objectively describe social relationships, especially with respect to religion. The rhizomatic can 
be understood as a way to subvert vertical structures in societies: structures of hierarchy, structures of transcendence. The Chinese Confucian model often emphasizes these vertical structures. Haiyan Lee talks about a "web of "rhizomatic" linkages that both support and subvert the vertical, "arborescent" structures of orthodoxy" (Lee 2010, p. 32). Rhizomatic thinking is therefore in particular important for religion in China. For Lee, there is a strong emancipatory notion associated with the rhizomatic:

"The rhizomatic realm has little regard for vertical social distinctions such as status, family background, and gender. Although the class hierarchy has always to some extent been mitigated and made porous by the ideal, if not the practice, of meritocracy and men of humble station could always hitch their ambitions of upward mobility to the civil service examinations, women have traditionally had little latitude in circumventing the Confucian gender hierarchy. Besides religious celibacy, entering the rhizomatic realm to become a woman warrior or a courtesan seems to be the only culturally condoned, if not encouraged, avenue of transcending or escaping the Confucian prescriptions of womanhood". (Lee 2010, p. 32)

Mayfair Yang has described how in China, social relationships form the network of society, represented by the concept guānxi 关系. From a Confucian point of view, these relations are hierarchical. But if we look closer, you can see how these relationships, constructed on the Confucian model, form large networks of interconnected individuals and communities in which there is no central node: "the "rhizomatic" (decentered and meandering) growth of practical kinship extends beneath and crisscrosses the centripetal, arborescent structures of the state and is therefore potentially subversive" (Lee's reference to (Yang 1994, pp. 304-11)).

Similar to how C.K. Yang has shown how "popular religion" functions as the impalpable subcurrent to official religion, Mayfair Yang emphasizes the subversive potential of the rhizomatic structure of Chinese religion and society. Though the official and elite hermeneutics of religious diversity emphasize the tradition of the jiào教, when observing Chinese religion as an anthropologist, a rhizomatic structure emerges, in which religious culture is constituted of a diverse web of practices, beliefs, superstitions, social duties, commitments, and allegiances. This rhizomatic fabric of society enables the possibility to subvert the dominant discourse. In the words of Haiyan Lee:

"The rhizomatic mode of sentimentality is sustained by a heterogeneity of beliefs, fantasies, and practices that seek to redress the injustices, contradictions, and inadequacies of the dominant social order. Here sentiment is about observing the protocols for dealing with fairies and ghosts or the rules of play between dandies and courtesans in the floating world of sensual pleasures". (Lee 2010)

This analysis of Chinese religion shows us the encounter between a hermeneutics of multiple religions and a hermeneutics of religiosity. The official hermeneutics of the Three Teachings is subverted by the shamanistic and popular practices in the everyday lives of Chinese people. Confucian ethics prescribes loyalty from a son to his father and from a wife to her husband. Lee refers to the Jianhu tales, in which female characters often subvert the common order, in danger of being punished or exorcised by shamans.

"Martial heroines pride themselves on their valor, martial skills, spirit of righteousness (yiqi), and devotion to sworn brothers and sisters. And yet, like their romantic counterpart, they are also proud of their respect for the moral order and its human embodiments: the emperor and parents. They are often maddening sticklers for decorum, and not a few have become memorable moral paragons in literary and popular histories. It is in this sense that the vertical and horizontal axes of sentimentality are mutually reinforcing. However, with its hidden transcripts, meandering structures, and fluid identities, the rhizomatic realm is always in excess of orthodoxy and thus a perennial source of anxiety and an intermittent target of appropriation and co-optation". (Lee 2010) 
These types of gender-critical approaches to religion, as we see in this citation, show that common understandings of religions and religious orthodoxies often excludes the religious experiences of women. Manuela Kalsky argues that women who experiment with eclectic forms of religiosity should be studied from their own experiences instead of theoretical discourses about faith or religion. She argues: "I would prefer the image of a network of lines. Lines, which are crossing and diverging, and at other moments converging, so that at time boundaries between one and the other are hardly visible". She questions whether "[it is] possible in theology to view religious identity as a part of a transcultural and trans-religious rhizome? Not a root-tree structure, not a solid anchoring in one religion, but a fluid and changeable process of moments of identification" (Kalsky 2017).

Following Mayfair Yang and Haiyan Lee, and also in line with feminist theologians in the West such as Michelle Voss Roberts (2010) and Manuela Kalsky (2017), I think that we should reimagine religious belonging as rhizomatic belonging. The concept "rhizomatic belonging", in my terminology, combines the multiplicity and decentrality of religious forms, with the very unique, personal, and unitary feeling of religious "belonging". Rhizomatic belonging can applied to both religion in East Asian, and to religion in general. This approach has several advantages. First, I think that the idea of "belonging" in a hermeneutics of multiple religions is too strongly connected to an understanding of belonging as "possessive", as Michelle Voss Roberts (2010) has also argued. The addition of the concept of the "rhizome" liberates the concept of "belonging" from the connotation with possession, as if religions "own" their followers.

Second, the idea of "belonging" in a hermeneutics of multiple religions is not very different from the concept of "identity". Belonging to Christianity means being a Christian. In the sociological understanding of both terms, "belonging" and "identity" are not usually distinguished. There is however, a strong emotional connotation attached to the concept of belonging. The word "belonging" harbors the root of "longing", or desire, and also, belonging is strongly related to a feeling of "being at home" or "being in the right place". It is important to appreciate "belonging" in its semantic dimension of affectivity and interiority. This does not mean that we henceforth all belong to a sort of true principle beyond religious traditions, such as humanity, God, truth or even "the Earth". Although the religious expresses our "ultimate concern" (Tillich [1957] 2009), our feeling of belonging that results from this concern is particular and dynamic.

Therefore, third, the metaphor of the rhizome expresses the dynamic, horizontal, multiple, and interconnected aspects of religious forms and assemblages. The idea of rhizomatic belonging expresses the particular and the interconnected. It does not strongly emphasize religious traditions, without ignoring them altogether. But it also doesn't exchange "religions" for a pluralistic universalism which understands all religions as fundamentally the same. And it is in this sense, I believe, that many people belong religiously. They feel connected to something which transcends them, but this feeling is particular, though not insular. They rhizomatically and transversally encounter movements in religious culture that we, in a hermeneutics of multiple religions, would call traditions, as well as other cultural forms that will inform their religious self-understanding, practices and commitments. Rhizomatic belonging expresses the hybrid nature of the cultural codes that fill individuals lives with meaning.

\section{Conclusions}

From a rhizomatic perspective, religions are not seen as bounded entities, but rather as networks or assemblages of elements which sometimes group together to form larger networks, sometimes, exclude other structures, but are often connected in many ways to other religious segments of society. What we imagine as "Buddhism" or "Daoism" in a hermeneutics of multiple religions, should better be described as networks of religious "words, things, gestures, powers, sounds, silences, smells, sensations, shapes, colours, affects and effects" (De Vries 2008). My term "rhizomatic belonging" can be used to address religious multiplicities of forms in East Asian religion and religion in general, though it retains the individual sense of unity towards a singular reality. On the one hand these networks have a gravity towards unification and exclusivism, resulting in the "reified imaginative formations" 
which we call "religions" (Hanegraaff 2016) on the other hand these networks are fundamentally open, inclusive, connected and transformative. For individuals, it is the challenge to navigate within this religious ecology. What can appear as rhizomatic belonging, as a religious practice observed from an etic perspective, is often much less related to religious identification from an emic perspective (Madsen 2014). We do however also witness the rise of Christian churches and new forms of Buddhism in East Asia, in which religious identity and exclusive belonging in the classical meaning do play a pivotal role (Tang 2013). Religious realities emerge as a result of our theory of religion, and these religious realities in turn inform our theory. Therefore, the relationship between phenomenology of religion and theory of religion can never be completely disentangled. In fact, we have to acknowledge that our conceptualizations of religious diversity are always already influenced by our valuation of those cultural expressions that we have come to call "religious".

Funding: My research on multiple religious belonging was funded by the Netherlands Organisation for Scientific Research (NWO) as part of their research program "Religion in Modern Society" (2013-2018). My PhD Research Fellowship at the Faculty of Philosophy at Renmin University of China in 2018 was funded by the Confucius Institute (Hanban).

Conflicts of Interest: The author declares no conflict of interest. The funders had no role in the design of the study; in the collection, analyses, or interpretation of data; in the writing of the manuscript, or in the decision to publish the results.

\section{References}

Asad, Talal. 2009. Genealogies of Religion: Discipline and Reasons of Power in Christianity and Islam. Baltimore: Johns Hopkins University Press. First published 1994.

Berghuijs, Joantine. 2017. Multiple Religious Belonging in the Netherlands: An Empirical Approach to Hybrid Religiosity. Open Theology 3: 19-37. [CrossRef]

Chau, Adam Yuet. 2011. Modalities of Doing Religion and Ritual Polytropy: Evaluating the Religious Market Model from the Perspective of Chinese Religious History. Religion 41: 547-68. [CrossRef]

Cornille, Catherine, ed. 2010. Many Mansions? Multiple Religious Belonging and Christian Identity. Eugene: Wipf \& Stock Publishers.

D'Costa, Gavin, and Ross Thompson, eds. 2016. Buddhist-Christian Dual Belonging: Affirmations, Objections, Explorations. Surrey: Ashgate.

De Vries, Hent. 2008. Religion: Beyond a Concept. New York: Fordham University Press.

Deleuze, Gilles, and Félix Guattari. 1987. A Thousand Plateaus: Capitalism and Schizophrenia. Minneapolis/London: University of Minnesota Press. First published 1980.

Goossaert, Vincent. 2005. The Concept of Religion in China and the West. Diogenes 52: 13-20. [CrossRef]

Hanegraaff, Wouter J. 2016. Reconstructing “Religion” from the Bottom Up. Numen 63: 577-606. [CrossRef]

Hedges, Paul. 2017. Multiple Religious Belonging after Religion: Theorising Strategic Religious Participation in a Shared Religious Landscape as a Chinese Model. Open Theology 3: 48-72. [CrossRef]

Kalsky, Manuela. 2017. Flexible Believers in the Netherlands: A Paradigm Shift toward Transreligious Multiplicity. Open Theology 3: 345-59. [CrossRef]

Lagerwey, John. 2010. China: A Religious State. Hong Kong: University of Hong Kong.

Lee, Haiyan. 2010. Revolution of the Heart: A Genealogy of Love in China, 1900-1950. Stanford and London: Stanford University Press.

Madsen, Richard. 2014. Secular Belief, Religious Belonging. Review of Religion and Chinese Society 1: 13-28. [CrossRef]

Masuzawa, Tomoko. 2012. The Invention of World Religions: Or, How European Universalism Was Preserved in the Language of Pluralism. Chicago: University of Chicago Press.

McGuire, Meredith B. 2008. Lived Religion: Faith and Practice in Everyday Life. Oxford and New York: Oxford University Press.

Palmer, David. A. 2013. China's Religious Landscape: Models of Religious Pluralism. Paper presented at the Bahá'i Chair for World Peace Fall Lecture, University of Maryland, College Park, MD, USA, November 25.

Palmer, David A., and Vincent Goossaert. 2011. The Religious Question in Modern China. Chicago: The University of Chicago Press. 
Palmer, David A., and Elijah Siegler. 2018. Dream Trippers: Global Daoism and the Predicament of Modern Spirituality. Chicago: The University of Chicago Press.

Parr, Adrian. 2010. The Deleuze Dictionary. Edinburgh: Edinburgh University Press.

Pew Forum on Religion \& Public Life. 2009. Many Americans Mix Multiple Faiths. Washington: Pew Research Center. Rajkumar, Peniel Jesudason Rufus, and Joseph Prabhakar Dayam, eds. 2016. Many yet One?: Multiple Religious Belonging. Geneva: World Council of Churches Publications.

Schmidt-Leukel, Perry, and Reinhold Bernhardt, eds. 2008. Multiple Religiöse Identität: Aus Verschiedenen Religiösen Traditionen Schöpfen. Zürich: Theologischer Verlag.

Smith, Jonathan Z. 1998. Religion, Religions, Religious. In Critical Terms for Religious Studies. Edited by Mark C. Taylor. Chicago: University of Chicago Press, pp. 179-96.

Tang, Edmond. 2013. Identity and Marginality-Christianity in East Asia. In Christianity in Asia. Edited by Felix Wilfred. Oxford: Oxford University Press, pp. 31-50.

Tillich, Paul. 2009. Dynamics of Faith. New York: HarperOne. First published 1957.

Voss Roberts, Michelle. 2010. Religious Belonging and the Multiple. Journal of Feminist Studies in Religion 26: 43-62. [CrossRef]

Wenzel-Teuber, Katharina. 2012. People's Republic of China: Religions and Churches Statistical Overview 2011. Religions \& Christianity in Today's China II: 29-54.

Yang, Mayfair Mei-Hui. 1994. Gifts, Favors, and Banquets: The Art of Social Relationships in China. Ithaka: Cornell University Press.

Yang, Mayfair Mei-hui. 2008. Chinese Religiosities Afflictions of Modernity and State Formation. Berkeley: University of California Press.

Yang, Fenggang. 2016. Exceptionalism or Chinamerica: Measuring Religious Change in the Globalizing World Today. Journal for the Scientific Study of Religion 55: 7-22. [CrossRef]

Yang, Fenggang. 2018. Religion in the Global East: Challenges and Opportunities for the Social Scientific Study of Religion. Religions 9: 305. [CrossRef]

Yao, Xinzhong, and Yanxia Zhao. 2010. Chinese Religion: A Contextual Approach. London and New York: Continuum.

(C) 2019 by the author. Licensee MDPI, Basel, Switzerland. This article is an open access article distributed under the terms and conditions of the Creative Commons Attribution (CC BY) license (http:/ / creativecommons.org/licenses/by/4.0/). 